Techniques \& Culture

Revue semestrielle d'anthropologie des techniques

$7 \mid 1986$

De l'Himalaya au haut Atlas. De l'Asir aux Andes

\title{
De l'Asir et des Andes
}

\section{François-René Picon}

\section{OpenEdition}

Journals

Édition électronique

URL : https://journals.openedition.org/tc/919

DOI : $10.4000 /$ tc. 919

ISSN : 1952-420X

Éditeur

Éditions de l'EHESS

Édition imprimée

Date de publication : 1 septembre 1986

ISSN : 0248-6016

Référence électronique

François-René Picon, « De l'Asir et des Andes », Techniques \& Culture [En ligne], 7 | 1986, mis en ligne le 23 janvier 2006, consulté le 29 septembre 2022. URL : http://journals.openedition.org/tc/919; DOI https://doi.org/10.4000/tc.919

Ce document a été généré automatiquement le 29 septembre 2022

Tous droits réservés 


\section{De l'Asir et des Andes}

François-René Picon 